\title{
A new rock-based definition for the Cryogenian Period (circa 720 - 635 Ma)
}

\author{
${ }^{1}$ Department of Earth Sciences, University College London, Gower Street, London WC1E 6BT, UK. E-mail: g.shields@ucl.ac.uk \\ ${ }^{2}$ State Key Laboratory of Palaeobiology and Stratigraphy, Nanjing Institute of Geology and Palaeontology, Chinese Academy of Sciences, \\ No.39 East Beijing Road, Nanjing 210008, China.E-mail: g.shields@nigpas.ac.cn \\ ${ }^{3}$ Department of Earth Science, University of California at Santa Barbara, CA 93106, USA. E-mail: porter@geol.ucsb.edu \\ ${ }^{4}$ Department of Earth \& Planetary Sciences/Geotop, McGill University, 3450 University Street, Montreal, Quebec, H3A 0E8 Canada. \\ E-mail:galen.halverson@mcgill.ca
}

(Received: 20/03/2015; Accepted:18/08/2015)

DOI:10.18814/epiiugs/2016/v39i1/XXXXX

The Cryogenian Period was first established in 1988 along with other Precambrian eon, era and period-level subdivisions that were defined numerically by Global Standard Stratigraphic Ages (GSSAs). As absolute age constraints have improved, some of these time intervals no longer bracket adequately the geological event(s), for which they were named. For example, the age discrepancy between the basal Cryogenian GSSA at 850 $\mathrm{Ma}$ and the onset of widespread glaciation ca. $717 \mathrm{Ma}$ has rendered the $850 \mathrm{Ma}$ boundary obsolete. The International Commission on Stratigraphy has now formally approved the removal of the Cryogenian GSSA from its International Chronostratigraphic Chart and supports its replacement with a rock-based Global Stratotype Section and Point (GSSP). The new Cryogenian GSSP will be placed at a globally correlative level that lies stratigraphically beneath the first appearance of widespread glaciation and is assigned in the interim a 'calibrated age' of circa 720 Ma. This new definition for the Tonian/Cryogenian boundary should be used in future publications until a formal Cryogenian GSSP can be ratified. The change marks progress towards establishment of a 'natural' (rock-based) scale for Precambrian time.

\section{Evolution of the Cryogenian Period concept}

The notion of a widespread glaciation during the late Precambrian was already well advanced (e.g. Kulling, 1934; Lee, 1936; Mawson, 1949) by the time Brian Harland (Harland, 1964a,b) suggested using glacial deposits to define a new addition to the international geological timescale. Harland's Infracambrian or Varangian System (Fig. 1) began at the onset of the great "Infracambrian" glaciations and ended at the appearance of recognised Cambrian fossil assemblages. The Subcommission on Pre-Cambrian Stratigraphy did not favour the term 'Infracambrian' and suggested its abandonment along with 'Eocambrian' and 'Subcambrian' in 1969. The term 'Precambrian' survived the cull despite calls for its removal (e.g. Cloud and Glaessner, 1982), while 'Infracambrian' still persists today without the precise stratigraphic significance given by Harland.

In 1971, Dunn et al. took up the case for a 'Late Pre-Cambrian' system beginning at the base of the Sturtian glacial deposits of South Australia. This informal new system attracted widespread support among the geological community and was referred to variously as the "Vendian" (based on the stratigraphy of the East European and Siberian platforms) or the "Sinian" (based on the stratigraphy of South China), covering Neoproterozoic glacial deposits and overlying Precambrian strata (e.g. Harland, 1982). Harland continued to augment his Infracambrian concept, suggesting that the Phanerozoic Eon be preceded by a Sinian Era, comprising Sturtian and Vendian divisions (Harland, 1982; 1990). Since the 1980's it has been commonplace to subdivide upper Precambrian strata (and time) using glaciogenic deposits and stratigraphic correlation of the successions in which they are found, e.g. Varanger, Elatina (Marinoan), Sturtian, etc.

Despite widespread use of these rock-based terms, purely chronometric subdivisions were introduced in 1988 for the preEdiacaran Precambrian (Plumb, 1991). As geochronological data have improved, it has become clear that some of these subdivisions do not accurately cover the aspect of Earth history to which their name refers. In the case of the Cryogenian Period, the chosen interval (850 Ma to c. $635 \mathrm{Ma}$ ) is now known to begin about 133 million years before the onset of widespread glaciation (Macdonald et al., 2010), a time span equivalent to the Cambrian, Ordovician, Silurian and early Devonian periods combined. The preceding period, the Tonian Period, was named for the rifting $($ Tonian $=$ stretching) associated with the breakup of the supercontinent Rodinia (Plumb and James, 1986; Plumb, 1991), which is now believed to have occurred only after $850 \mathrm{Ma}(\mathrm{Li}$ et al., 2013), when the Tonian Period had already ended. For such reasons, as well as the inherently imprecise nature of stratigraphic correlation using absolute age constraints (Bleeker, 2004), there has 


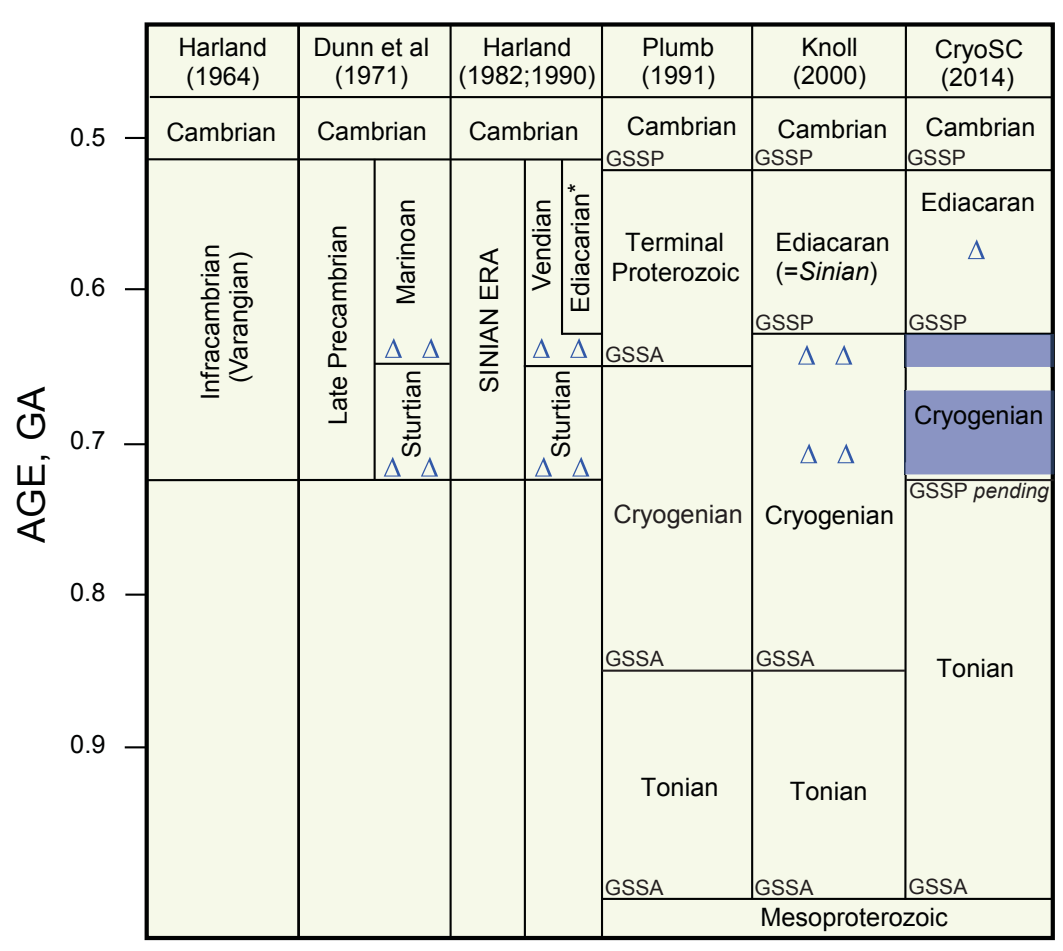

Figure 1: Evolutionary history of stratigraphic subdivisions, GSSAs and GSSPS covering the Neoproterozoic - Cambrian interval. Assigned stratigraphic levels and respective ages refer to current estimates of previously proposed rock-based or fossilbased subdivisions (not the authors' original age estimates). " $\ddot{A}$ ” represents Neoproterozoic glacial episodes and their relationship to proposed subdivisions in the corresponding original publications. These correspond to the localised Gaskiers glaciation at c. $580 \mathrm{Ma}$, and two intervals of low-latitude glaciations (shaded intervals) during the Cryogenian Period: the first (Sturtian) beginning in NW Canada at ca.716 Ma (Macdonald et al. 2010), and lasting possibly until ca. 665 Ma (Zhou et al., 2004; Rooney et al., 2014), and a second (Marinoan), which lasted from about $645 \mathrm{Ma}$ until the base of the Ediacaran at ca. $635 \mathrm{Ma}$ (e.g. Condon et al., 2005). *Cloud and Glaessner (1982); CryoSC (2014) refers to the newly defined rock-based Cryogenian Period.

been a move over the past decade or so to abandon all such chronometric subdivisions in favour of a rock-based, 'natural' Precambrian time scale using the GSSP concept of global stratotypes.

The first Precambrian System to be defined using a basal GSSP was the Ediacaran System. The recognition of undisputed soft-bodied organic remains, including many of possible animal grade, in uppermost pre-Cambrian strata from Australia (Sprigg, 1947; Glaessner, 1982), and increasingly from other localities (Fedonkin, 1990; Narbonne 2005), led some to propose either a division of the Vendian into two epochs (Harland and Herod, 1975; Harland, 1990) or the creation of a separate period (system) which incorporated these fossil remains. The base of the new Ediacaran System was proposed within pink-coloured, post-glacial dolostones in South Australia (Cloud and Glaessner, 1982). Such 'cap carbonate' dolostone units were postulated to be correlative (Dunn et al., 1971) and are now known to be both globally widespread (Knoll et al., 2004) and synchronous (Hoffmann et al., 2004; Condon et al., 2005; Calver et al., 2013; Rooney et al., 2015). The Ediacarian period of Cloud and Glaessner (1982) was 'set in stone' by the international geological community when the new 'Ediacaran' System was ratified in 2004, carved out of the provisional Neoproterozoic III (Plumb, 1991).

The Ediacaran GSSP was a significant departure from the
Phanerozoic convention in that for the first time a GSSP was defined based on a geochemical and palaeoclimatic (chemo-oceanographic) event, rather than using biostratigraphy. Although Ediacaran fossil assemblages, both macro- and microscopic, are well-known, underlying Cryogenian strata so far exhibit limited potential for biostratigraphy (see below). For these reasons, Andrew Knoll, when chair of the Terminal Proterozoic Subcommission, advocated a chronostratigraphic definition for the base of Cryogenian System marked by the first 'Sturtian' glacial rocks (Knoll, 2000). However, even if glacial influence could be demonstrated unambiguously in the chosen section (Etienne et al., 2008), the onset of glaciogenic deposition in one region may not correspond to a globally correlative stratigraphic horizon due to geographic variability and sub-glacial erosion (e.g. Kendall et al., 2009).

With these difficulties in mind, the International Subcommission on Neoproterozoic Stratigraphy (ISNS) agreed that an integrated but predominantly geochemical approach might be the best way to define a rock-based Cryogenian System (Shields-Zhou et al., 2012). The ISNS proposed that the base of any Cryogenian System would need to be within an outcrop section at a precisely defined stratigraphic level (GSSP) that was clearly beneath the oldest unambiguously glaciogenic deposits. Precise definition and correlation of such a GSSP would require high resolution $\mathrm{C}$ - and $\mathrm{Sr}$-isotope data, together with a combination of microfossil, magneto-stratigraphic and absolute age constraints. By prioritising chemostratigraphic criteria, it was implicitly understood that the future GSSP could only be established in a carbonate rock succession that would almost inevitably underlie a sedimentary gap caused by erosion of the carbonate platform during eustatic sea level fall. The alternative option-for a GSSP to be placed beneath a more transitional glaciogenic stratigraphic succession-was less highly favoured by the Neoproterozoic Subcommission due to the inherently greater difficulties in correlating strata from deeper, predominantly siliciclastic settings in the absence of an adequate geochronological and/or biostratigraphic framework.

In 2012, the Neoproterozoic Subcommission was succeeded by two new international subcommissions for the Cryogenian and the Ediacaran systems, respectively. The objective of the Cryogenian Subcommission is to establish a GSSP for the base of the Cryogenian System in a five-step process. International agreement on criteria for definition and correlation of the GSSP was the first step. The next step is to replace the existing GSSA with the new rock-based definition, pending discussion, selection and eventual ratification of the GSSP. For the removal of the existing GSSA to be adopted consistently, an interim age needs to be assigned. This was done previously for the Ediacaran (Neoproterozoic III) Period, which was initially assigned a provisional age of $650 \mathrm{Ma}$ (Plumb, 1991), and then corrected to 635 Ma once the GSSP could be established (Knoll et al., 2006). The International Commission on Stratigraphy (ICS) has now approved the removal of the Cryogenian GSSA from all official versions of the geological time scale, and accepted our recommendation that the interim 'calibrated' age for the base of the Cryogenian System be set at ca. 720 Ma. 


\section{Direct age constraints on the onset of glaciation}

Recent U-Pb and Re-Os data confirm that the Cryogenian glacial interval comprises two main episodes (ca. 717- ca. $662 \mathrm{Ma}$ and ca. 645 - ca. $635 \mathrm{Ma}$; Rooney et al., 2015). Although possibly older glaciogenic diamictites have been reported (e.g. Kaigas Formation, Frimmel et al. 1996), these rare exceptions have not yet been fully substantiated by stratigraphical, sedimentological or geochronological data. The two most pertinent syn-glacial ages for the older of the two glaciations are the $716.5( \pm 0.3)$ Ma for the Rapitan glacials in NW Canada (Macdonald et al., 2010) and the $714( \pm 1)$ Ma for the Gubrah Formation of Oman (Bowring et al., 2007; see Allen, 2007); note that this latter age has also been cited as $711.8( \pm 1.6)$ Ma (Allen et al., 2002) but has not been published. These ages represent minimum age constraints for the onset of widespread glaciation at low latitudes during the Neoproterozoic, and are consistent with a wealth of maximum age data from strata beneath glaciogenic units (e.g. Rooney et al., 2014; Strauss et al., 2014; Hoffman et al., 1996). Precise U-Pb zircon maximum age constraints for the onset of glaciation are provided by a pre-glacial age of $726( \pm 1)$ Ma for the Leger granite, which predates deposition of the entire Mirbat Group in Oman (Allen, 2007) and 719.5 \pm 0.3 Ma for the Kikiktak Volcanics, beneath the Hula Hula Diamictite in Arctic Alaska (Cox et al., 2015). Re-Os isochron ages of 727.3 $\pm 4.9 \mathrm{Ma}$ for the upper Mwashya Formation, beneath the Grand Conglomerat in Zambia and 732.2 \pm 4.7 Ma for the Coppercap Formation beneath the Rapitan Group in NW Canada provide complementary maximum age constraints. Together, these ages are consistent with the pre-glacial age of $717.4( \pm 0.2)$ Ma from NW Canada (Macdonald et al., 2010), which together with the synglacial age $(716.5( \pm 0.3) \mathrm{Ma})$ from the same region, tightly constrain the onset of low latitude glaciation during the Neoproterozoic at ca. 717 Ma.

Only few successions in the world preserve a transition into Neoproterozoic glaciation because of the erosion caused by eustatic sea-level fall and sub-glacial scouring. The most likely settings where such a transition might be preserved are deeper ones, such as those from parts of South China (northern Guangxi and southern Hunan and Guizhou provinces) where lonestones appear within turbiditic mudstones above a volcanic tuff layer dated recently at $715.9 \pm 2.8$ Ma and 716.9 $\pm 3.4 \mathrm{Ma}$ (Lan et al., 2014). These new age constraints from thick, transitional pre-glacial successions support (1) approximately contemporaneous onset of glaciation on a global scale during the mid-Neoproterozoic; and (2) the lack of any widespread glacial deposits of Neoproterozoic age substantially older than about $717 \mathrm{Ma}$. The above arguments provide firm support to the proposed interim, calibrated age for the base of the Cryogenian System of ca. 720 Ma.

\section{Stratigraphic correlation of the Tonian- Cryogenian transition}

Chemostratigraphy is currently the method of choice for correlating pre-glacial Neoproterozoic strata. Pre-glacial carbonate platforms (Fig. 2) commonly exhibit an extreme negative $\delta^{13} \mathrm{C}$ excursion (referred to as the Islay anomaly). It has been proposed
Ogilvie Mtns, Yukon

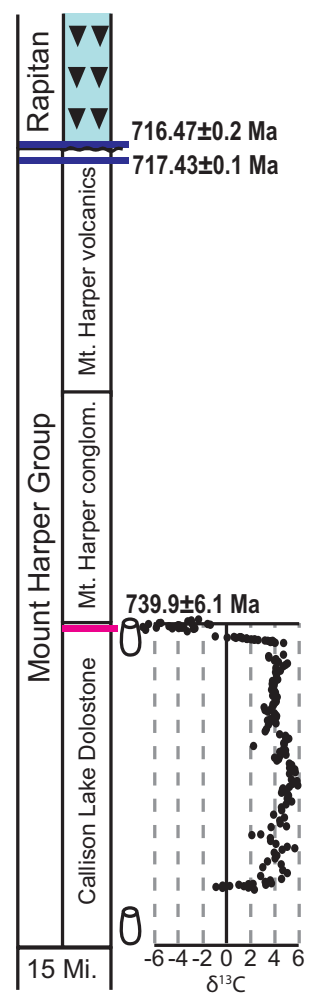

Mackenzie Mtns, NWT

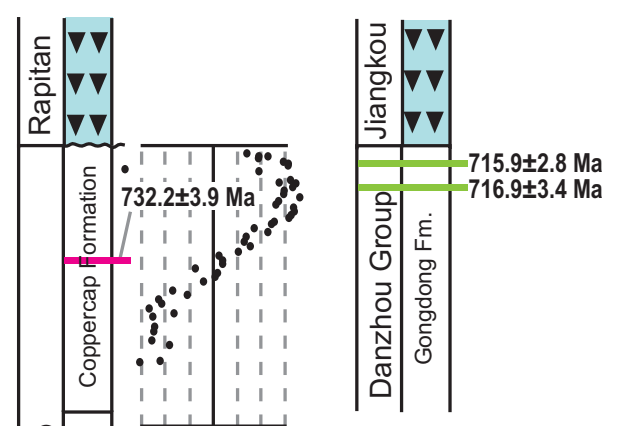

Figure 2: Key successions that provide radiometric contraints and/or biostratigraphic and chemostratigraphic data relevant to the Cryogenian GSSP. Figure based on Strauss et al. (2014), with data from Macdonald et al. (2010) and Strauss et al. (2014) (Ogilvie Mtns); Rooney et al. (2014) (Mackenzie Mtns); Lan et al. (2014) (Nanhua Basin); Knoll et al. (1989, 1991) and Halverson et al. (2005) (Svalbard); and Prave et al. (2009) and Anderson et al. (2014) (Scotland). Meterage for all sections indicated in key. 
that the implied carbon cycle perturbation was causally related to the onset of Cryogenian glaciation (Schrag et al., 2002). However, recent Re-Os age constraints imply that the Islay anomaly in Scotland (correlated to Greenland, Svalbard and NW Canada) could predate the onset of Cryogenian glaciation by at least 15 million years (Strauss et al., 2014; Fig. 2), and that the Coppercap Formation (Mackenzie Mountains, NW Canada) may preserve a more complete, but still truncated pre-glacial succession.

In the Coppercap Formation, the pre-glacial negative anomaly is followed by a recovery to high positive $\delta^{13} \mathrm{C}$ values that might have been removed by erosion in Scotland and Svalbard. In the Mackenzie Mountains, this $\delta^{13} \mathrm{C}$ recovery is accompanied by decreasing ${ }^{87} \mathrm{Sr} /{ }^{86} \mathrm{Sr}$ from a high of $\sim 0.7067-70$ to $\sim 0.7065$ (Rooney et al., 2014), followed by a modest rise back to $\sim 0.7066-67$. The range and trend of ${ }^{87} \mathrm{Sr} /{ }^{86} \mathrm{Sr}$ values are similar in Scotland, but there the negative $\delta^{13} \mathrm{C}$ anomaly does not recover back to high positive values, and it is accompanied by a fall in ${ }^{87} \mathrm{Sr} /{ }^{86} \mathrm{Sr}$ from $\sim 0.7066-70$ before the anomaly to $\sim 0.7065 \pm 1$ during the anomaly (Brasier and Shields, 2000; Sawaki et al., 2010). Sparse data from Svalbard exhibit unchanging ${ }^{87} \mathrm{Sr} /{ }^{86} \mathrm{Sr}$ values of $\sim 0.7067$ before the negative anomaly (Halverson et al., 2007), whereas data from carbonates which postdate the anomaly in East Greenland yielded least altered values of 0.7063-64 (Fairchild et al., 2000). Assuming that these negative excursions all relate to the same pre-glacial Islay anomaly, the existing $\mathrm{C}$ isotope data support the idea that the Mackenzie Mountains region (and possibly E Greenland sections) provides the most complete of the best-known pre-glacial carbonate successions. However, the Sr isotope record, although generally supportive of mutual correlation between these sections, is ambiguous in its detail. ${ }^{87} \mathrm{Sr} /{ }^{86} \mathrm{Sr}$ values are notoriously susceptible to diagenetic alteration, while $\mathrm{C}$ isotope stratigraphy remains untested for much of the Precambrian due to the absence of an adequate biostratigraphic framework. Additional work is needed

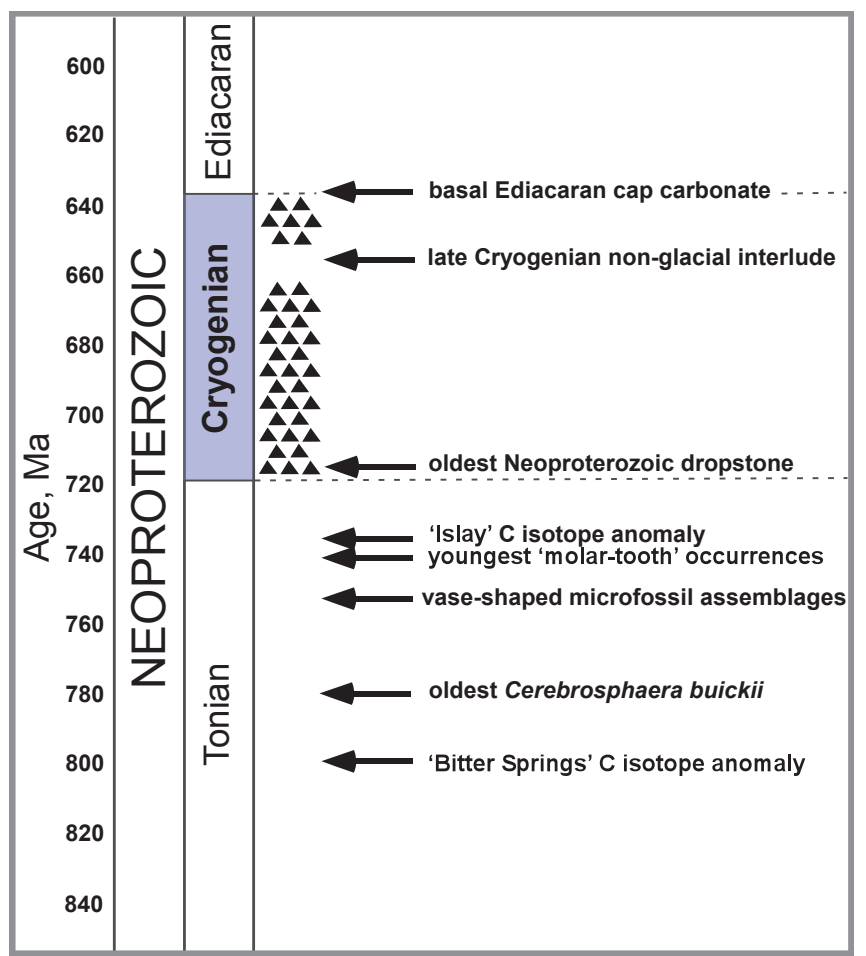

Figure 3. Major events associated with the newly defined Cryogenian Period and the Tonian-Cryogenian interval. to verify that $\mathrm{Sr}$ - and $\mathrm{C}$-isotope trends can be reproduced regionally and globally and that the negative anomaly in the Coppercap Formation is the same as the pre-glacial anomaly found in Svalbard and Scotland.

Despite the focus on chemostratigraphy, a number of fossil groups show potential as global time markers. For example, the appearance of several species of vase-shaped microfossils (VSMs) worldwide between circa $770 \mathrm{Ma}$ and $740 \mathrm{Ma}$ (Figs. 2-3) could provide additional means to correlate and define the onset of the Cryogenian (Porter et al., 2003; Strauss et al., 2014), and slightly older strata preserve distinctive widespread acritarch species that could prove useful (Fig. 3; Porter and Riedman, in press).

\section{A prescription for future subdivision of Proterozoic strata?}

The newly defined Cryogenian Period began about 720 million years ago and continued until $635 \mathrm{Ma}$; its shorter c. 95 million-year duration now resembles its Phanerozoic counterparts. One inevitable consequence of this redefinition is that the Tonian-Cryogenian boundary has leaped forward in time from $850 \mathrm{Ma}$ to ca. $720 \mathrm{Ma}$, rendering the Tonian Period exceptionally long (1000 - ca. 720 Ma). In recognition of the fact that the term 'Tonian' refers to the stretching caused by the break-up of the supercontinent Rodinia (Plumb, 1991), which began only after ca. $850 \mathrm{Ma}$, we consider that the Tonian Period may also undergo radical redefinition, possibly triggering formulation of a new period for the earliest Neoproterozoic.

\section{References}

Allen, P.A., 2007. The Huqf Supergroup of Oman: basin development and context for Neoproterozoic glaciation. Earth Science Reviews, v. 84, pp. 139-185.

Allen, P.A., Bowring, S., Leather, J., Brasier, M.D., Cozzi, A., Grotzinger, J.P.,McCarron, G., Amthor, J.E., 2002. Chronology of Neoproterozoic glaciations: new insights from Oman. 16th International Sedimentological Congress, Johannesburg, South Africa, Abstract Volume, pp. 7-8.

Anderson, R.P., Fairchild, I.J., Tosca, N.J., Knoll, A.H., 2014. Microstructures in metasedimentary rocks from the Neoproterozoic Bonahaven Formation: Microconcretions, impact spherules or microfossils? Precambrian Research, v. 233, pp. 59-72.

Bleeker, W., 2004. Towards a 'natural' time scale for the Precambrian -A proposal. Lethaia, v. 37, pp. 219-222.

Bowring, S., Grotzinger, J.P., Condon, D.J., Ramezani, J., Newall, M., Allen, P.A., 2007. Geochronologic constraints on the chronostratigraphic framework of the Neoproterozoic Huqf Supergroup, Sultanate of Oman. American Journal of Science, v. 307, pp.1097-1145.

Brasier, M.D., Shields, G.A., 2000. Neoproterozoic chemostratigraphy and correlation of the Port Askaig glaciation, Dalradian Supergroup of Scotland. Journal Geological Society of London, v. 157, pp. 909-914.

Calver, C.R., Crowley, J.L., Wingate, M.T.D., Evans, D.A.D., Raub, T.D., Schmitz, M.D., 2013. Globally synchronous Marinoan deglaciation indicated by U-Pb geochronology of the Cottons Breccia, Tasmania, Australia. Geology, doi: 10.1130/G34568.1

Cloud, P., Glaessner, M.F., 1982. The Ediacaran Period and system: metazoa inherit the Earth. Science, v. 217, pp.783-792.

Condon, D., Zhu, M., Bowring, S., Jin, Y., Wang, W., Yang, A., 2005. U-Pb ages from the Doushantuo Formation, China. Science, v. 308, pp. 95-98.

Cox, G.M., Strauss, J.V., Halverson, G.P., Schmitz, M.D., McClelland, W.D., Stevenson, R.S., Macdonald, F.M., 2015. Kikiktak Volcanics of Arctic Alaska-Melting of harzburgitic mantle associated with the Franklin Large Igneous Province. Lithosphere, v. 7(3), doi:10.1130/L435.1. 
Dunn, P.R., Thomson, B.P., Rankama, K., 1971. Late Pre-Cambrian glaciations in Australia as a stratigraphic boundary. Nature, v. 231, pp. 498-502.

Etienne, J.L., Allen, P.A., Rieu, R., Le Guerroué, E., 2008. Neoproterozoic glaciated basins: a critical review of the 'Snowball Earth' hypothesis by comparison with Phanerozoic glaciations. In: Hambrey, M., Christofferson, P., Glasser, N., Hubbard, B. (Eds.), Glacial Sedimentary Processes and Products. Blackwell, New York, pp. 343-399.

Fairchild, I.J., Spiro, B., Herrington, P.M., Song, T., 2000. Controls on Sr and $\mathrm{C}$ isotope compositions of Neoproterozoic Sr-rich limestones of East Greenland and North China. In: Grotzinger, J., James, N. (Eds.), Carbonate Sedimentation and Diagenesis in and Evolving Precambrian World. Special Publications Vol. 67, SEPM, Tulsa, pp. 297-313.

Fedonkin, M.A., 1990. Systematic description of Vendian Metazoa. In:Sokolov, B.S., Iwanowski, A.B. (Eds.), The Vendian System, Vol. 1:Palaeontology, English edition. Springer, Berlin, pp. 71-120.

Frimmel, H.E., Klötzli, U.S., Siegfried, P.R., 1996. New Pb-Pb single zircon age constraints on the timing of Neoproterozoic glaciation and continental break-up in Namibia. Journal of Geology, v. 104, pp. 459-469.

Glaessner, M.F., 1984. The dawn of animal life. Cambridge University Press, Cambridge, $244 \mathrm{pp}$.

Halverson, G.P., Hoffman, P.F., Schrag, D.P., Maloof, A.C., Rice, A.H.N., 2005. Towards a Neoproterozoic composite carbon-isotope record. GSA Bulletin, v. 117, pp. 1181-1207.

Halverson, G.P., Dudas, F.O., Maloof, A.C., Bowring, S.A., 2007. Evolution of the ${ }^{87} \mathrm{Sr} /{ }^{86} \mathrm{Sr}$ composition of Neoproterozoic seawater. Palaeogeography, Palaeoclimatology, Palaeoecology, v. 256, pp. 103-129.

Halverson, G.P., Wade, B.P., Hurtgen, M.T., Barovich, K.M., 2010. Neoproterozoic chemostratigraphy. Precambrian Research, v. 182, pp. 337-350.

Harland, W.B., 1964a. Critical evidence for a great infra-Cambrian glaciation. Geologische Rundschau, v. 54, pp. 45-61.

Harland, W.B., 1964b. Evidence of Late Precambrian glaciation and its significance. In: Nairn, A.E.M. (Ed.), Problems in Palaeoclimatology. Wiley Interscience, London, pp. 119-149 and 179-184.

Harland, W.B., Herod, K.N., 1975. Glaciations through time. In: Wright, A.E., Moseley, F. (Eds.), Ice Ages: ancient and modern. Seel House Press, Liverpool, pp. 189-216.

Harland, W.B., Cox, A.V., Llewellyn, P.G., Smith, A.G., Pickton, C.A.G., Walters, R., 1982. A Geologic Time Scale. Cambridge University Press, Cambridge, 131 pp.

Harland, W.B., Armstrong, R.L., Cox, A.V., Craig, L.E., Smith, A.G., Smith, D.G., 1990. A Geologic Time Scale 1989. Cambridge University Press, Cambridge, 263 pp.

Hoffman, P.F., Hawkins, D.P., Isachsen, C.E., Bowring, S.A., 1996. Precise $\mathrm{U}-\mathrm{Pb}$ zircon ages for early Damaran magmatism in the Summas Mountains and Welwitschia inlier, northern Damara belt, Namibia. Geological Survey of Namibia Communications, v.1, pp. 47-52.

Hoffmann, K.H., Condon, D.J., Bowring, S.A., Crowley, J.L., 2004. A U-Pb zircon date from the Neoproterozoic Ghaub Formation, Namibia: Constraints on Marinoan glaciation. Geology, v. 32, pp. 817-820.

Karlstrom, K.E., Bowring, S.A., Dehler, C.M., Knoll, A.H., Porter, S.M., Des Marais, D.J., Weil, A.B., Sharp, Z.D., Geissman, J.W., Elrick, M.B., Timmons, J.M., Crossey, L.J., Davidek, K.L., 2000. Chuar Group of the Grand Canyon: record of breakup of Rodinia, associated change in the global carbon cycle, and ecosystem expansion by 740 Ma. Geology, v. 28, pp.619-622.

Kendall, B., Creaser, R.A., Calver, C.R., Raub, T.D., Evans, D.A.D., 2009.Correlation of Sturtian diamictite successions in southern Australia and northwestern Tasmania by Re-Os black shale geochronology and the ambiguity of "Sturtian"-type diamictite cap carbonate pairs as chronostratigraphic marker horizons. Precambrian Research, v. 172, pp. 301-310.

Knoll, A.H., Swett, K., Burkhardt, E., 1989. Paleoenvironmental distribution of microfossils and stromatolites in the upper Proterozoic Backlundtoppen Formation, Spitsbergen. Jour Paleontology v. 63, pp. 129-145.
Knoll,A.H., Swett,K., Mark, J., 1991. Paleobiology of a Neoproterozoic tidal flat/lagoonal complex: the Draken Formation, Spitsbergen. Journal of Paleontology, v. 65, pp. 531-570.

Knoll, A.H., 2000. Learning to tell Neoproterozoic time. Precambrian Research, v. 100, pp. 3-20.

Knoll, A.H., Walter, M.R., Narbonne, GM., Christie-Blick, N., 2004. A New Period for the Geologic Time Scale. Science, v. 305, pp. 621-622.

Knoll, A.H., Walter, M.R., Narbonne, G.M., Christie-Blick, N., 2006. The Ediacaran Period: a new addition to the Geologic Time Scale. Lethaia v. 39 , pp. $13-30$.

Kulling, O., 1934. The Hecla Hoek Formation round Hinlopenstredet. Geografiska Annaler, v. 14, pp. 161-253.

Lan, Z.W., Li, X.H., Zhu, M.Y., Chen, C.Q., Zhang, Q.R., Li, Q.L., Lu, D.B., Liu, Y., Tang, G.Q., 2014, A rapid and synchronous initiation of the widespread Cryogenian glaciations. The Journal of the Geological Society (London), v. 255, pp. 401-411.

Lee, Y.Y., 1936. The Sinian glaciation in the lower Yangtze valley. Bulletin of the Geological Society of China, v. 15, pp. 131-134.

Li, Z., Evans, D.A.D., Halverson, G.P., 2013. Neoproterozoic glaciations in a revised global paleogeography from the breakup of Rodinia to the assembly of Gondwanaland. Sedimentary Geology, v. 294, pp. 213232

Macdonald, F.A., Schmitz, M.D., Crowley, J.L., Roots, C.F., Jones, D.S., Maloof, A.C., Strauss, J.V., Cohen, P.A., Johnston, D.T., Schrag, D.P.,2010. Calibrating the Cryogenian. Science 327, 1241-1243.

Mawson, D., 1949. The Late Precambrian ice age and glacial record of the Bibliando dome. Journal and Proceedings of the Royal Society of New South Wales, v. 82, pp. 150-174.

Narbonne, G.M., 2005. The Ediacara Biota: Neoproterozoic origin of animals and their ecosystems. Annual Review of Earth and Planetary Sciences, v. 33 , pp. 421-442.

Plumb, K.A., 1991. A new Precambrian timescale. Episodes, v. 14, pp. 139140.

Plumb, K.A., James, H.L., 1986. Subdivision of Precambrian time: recommendations and suggestions by the Commission on Precambrian stratigraphy. Precambrian Research, v. 32, pp. 65-92.

Porter, S. M., Meisterfeld, R., Knoll, A. H., 2003, Vase-shaped microfossils from the Neoproterozoic Chuar Group, Grand Canyon: a classification guided by modern testate amoebae: Journal of Paleontology, v. 77, pp. $409-429$

Porter, S. M., Riedman, L. A., in press, Systematics of organic-walled microfossils from the $\sim 780-740$ Ma Chuar Group, Grand Canyon, Arizona. Journal of Paleontology.

Prave, A.R., Strachan, R.A. \& Fallick, A.E., 2009. Global C cycle perturbations recorded in marbles: a record of Neoproterozoic Earth history within the Dalradian succession of the Shetland Islands, Scotland. Journal of the Geological Society, London, v. 166, pp. 129-135.

Rooney, A., Macdonald, F.A., Strauss, J.V., Dudás, F.Ö., Hallmann, C., Selby, D., 2014, Re-Os geochronology and coupled Os-Sr isotope constraints on the Sturtian snowball Earth. Proceedings of the National Academy of Sciences, v. 111, pp. 51-56.

Rooney, A. D., Strauss, J. V., Brandon, A. D., Macdonald, F. A., 2015. A Cryogenian chronology: Two long-lasting synchronous Neoproterozoic glaciations. Geology, v. 43, pp. 459-462.

Sawaki, Y., Kawai, T., Shibuya, T., Tahata, M., Omori, S., Komiya, T., Yoshida, N., Hirata, T., Ohno, T., Windley, B.F., Maruyama, S., 2010, ${ }^{87} \mathrm{Sr} /{ }^{86} \mathrm{Sr}$ chemostratigraphy of Neoproterozoic Dalradian carbonates below the Port Askaig Glaciogenic Formation, Scotland. Precambrian Research, v. 179(1), pp. 150-164.

Schrag, D.P., R.A. Berner, P.F. Hoffman, G.P. Halverson, 2002. On the initiation of a Snowball Earth. Geochem. Geophys. Geosyst., 10, Paper \#1029/2001GC000219.

Shields-Zhou, G.A., Hill, A.C., Macgabhann, B.A., 2012, The Cryogenian Period, In: The Geologic Time Scale 2012 (Eds. F.M. Gradstein, J.G. Ogg, M. Schmitz, G. Ogg), Elsevier B.V., Chapter 17, pp. 393411. 
Sprigg, R.C., 1947. Early Cambrian (?) jellyfishes from the Flinders Ranges, South Australia. Transactions of the Royal Society of South Australia, v. 71, pp.212-224.

Strauss, J.V., Rooney, A.D., Macdonald, F.A., Brandon, A.D., Knoll, A.H., 2014, 740 Ma vase-shaped microfossils from Yukon, Canada:

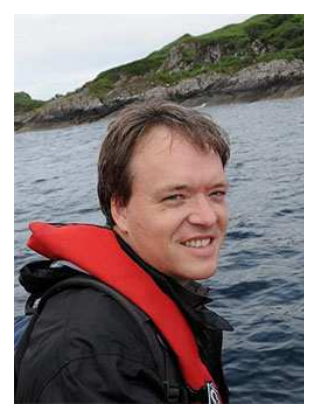

Graham Shields-Zhou is Professor of Geology at University College London, UK, and a visiting professor at the Nanjing Institute of Geology and Palaeontology, Chinese Academy of Sciences. Since completing his PhD at the ETH Zurich, Switzerland, he has worked in several countries on diverse aspects of sedimentary and environmental geochemistry, but has always been drawn back to the mysterious origins of complex life during the Neoproterozoic Era. Graham is the chair of the International Subcommission on Cryogenian Stratigraphy, whose task it is to work towards defining a GSSP for the new rock-based Cryogenian System.

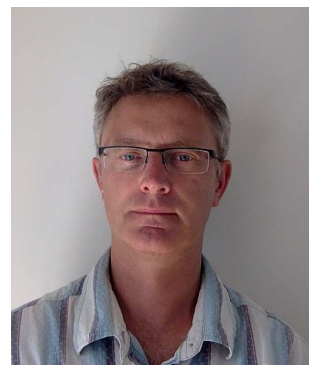

Galen Halverson is the T.H. Chair in sedimentary geology and petroleum geology at McGill University in Montreal, Canada, and vice-chair of the International Subcommission on Cryogenian Stratigraphy. His research involves a combination of fieldwork, basin analysis, and analytical geochemistry, largely dedicated to study of the Neoproterozoic Era (1000$541 \mathrm{Ma}$ ). The ultimate aim of this research is to document, calibrate, and interpret Earth system evolution spanning the great transition from a world that supported only relatively simple, mostly unicellular life to a habitable world that fostered the origin and rapid diversification of animal life.
Implications for Neoproterozoic chronology and biostratigraphy. Geology, v. 42, pp. 659-662.

Zhou, C., Tucker, R., Xiao, S., Peng, Z., Yuan, X., Chen, Z., 2004. New constraints on the ages of Neoproterozoic glaciations in South China. Geology, v. 32, pp. 437-440.

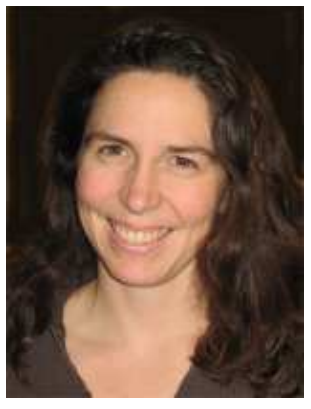

Susannah Porter, Associate Professor at the University of California, Santa Barbara, and Secretary of the International Subcommission on Cryogenian Stratigraphy. Susannah received her bachelor's degree in mathematics from Yale University in 1995 and her Ph.D. in Biology with Andrew Knoll at Harvard University in 2002. Susannah's research focuses on the early fossil record of animals and their protistan relatives. She has worked on problems relating to the evolution of skeletal biomineralization, the influence of snowball Earth glaciations on the diversity of life, the early evolution of eukaryotes, and the Cambrian diversification of animals. 